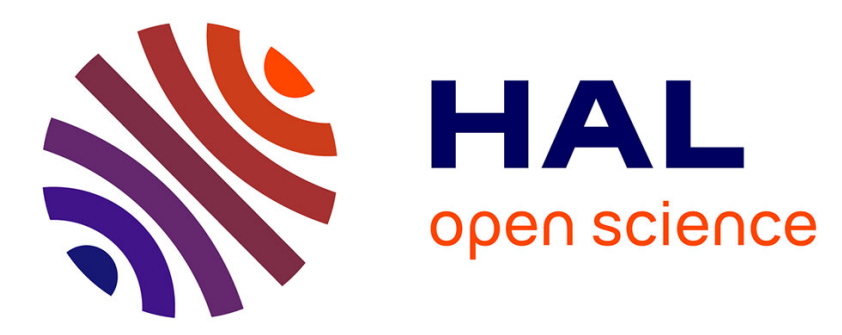

\title{
Mercury in 16 demersal sharks from southeast Australia: Biotic and abiotic sources of variation and consumer health implications
}

\author{
Heidi Pethybridge, Daniel Cossa, Edward C.V. Butler
}

\section{> To cite this version:}

Heidi Pethybridge, Daniel Cossa, Edward C.V. Butler. Mercury in 16 demersal sharks from southeast Australia: Biotic and abiotic sources of variation and consumer health implications. Marine Environmental Research, 2009, 69 (1), pp.18. 10.1016/j.marenvres.2009.07.006 . hal-00563093

\section{HAL Id: hal-00563093 https://hal.science/hal-00563093}

Submitted on 4 Feb 2011

HAL is a multi-disciplinary open access archive for the deposit and dissemination of scientific research documents, whether they are published or not. The documents may come from teaching and research institutions in France or abroad, or from public or private research centers.
L'archive ouverte pluridisciplinaire HAL, est destinée au dépôt et à la diffusion de documents scientifiques de niveau recherche, publiés ou non, émanant des établissements d'enseignement et de recherche français ou étrangers, des laboratoires publics ou privés. 


\section{Accepted Manuscript}

Mercury in 16 demersal sharks from southeast Australia: Biotic and abiotic sources of variation and consumer health implications

Heidi Pethybridge, Daniel Cossa, Edward C.V. Butler

PII:

S0141-1136(09)00102-0

DOI:

10.1016/j.marenvres.2009.07.006

Reference:

MERE 3359

To appear in:

Marine Environmental Research

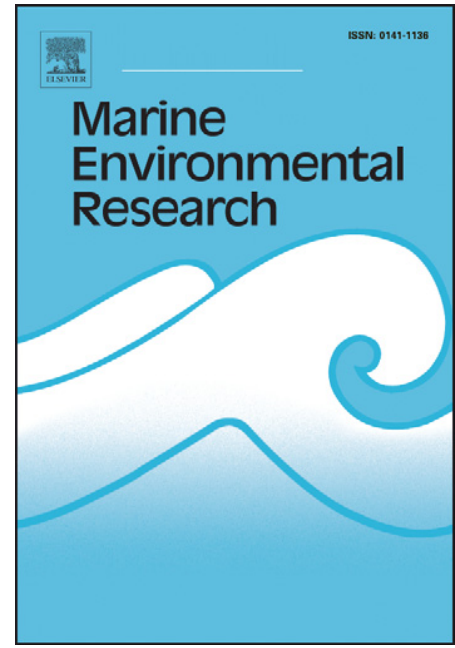

Received Date: $\quad 27$ March 2009

Revised Date: $\quad 21$ July 2009

Accepted Date: $\quad 22$ July 2009

Please cite this article as: Pethybridge, H., Cossa, D., Butler, E.C.V., Mercury in 16 demersal sharks from southeast Australia: Biotic and abiotic sources of variation and consumer health implications, Marine Environmental Research (2009), doi: 10.1016/j.marenvres.2009.07.006

This is a PDF file of an unedited manuscript that has been accepted for publication. As a service to our customers we are providing this early version of the manuscript. The manuscript will undergo copyediting, typesetting, and review of the resulting proof before it is published in its final form. Please note that during the production process errors may be discovered which could affect the content, and all legal disclaimers that apply to the journal pertain. 
Running title: Mercury in demersal sharks

\title{
Mercury in 16 demersal sharks from southeast Australia: Biotic and abiotic sources of variation and consumer health implications
}

Heidi PETHYBRIDGE ${ }^{1,3^{*}}$, Daniel COSSA ${ }^{2}$, Edward C.V. BUTLER ${ }^{3}$

(1) IASOS, University of Tasmania, Private Bag 77, Hobart, Australia

(2) IFREMER, Centre de Méditerranée, BP 330, F.83507 La Seyne sur mer, France,

(3) CSIRO Marine and Atmospheric Research, Castray Esplanade, Hobart, Australia

*Corresponding author: Email: heidi.Pethybridge@ csiro.au, +61 362325222 (Tel.)

\begin{abstract}
Total mercury (THg) and monomethylmercury (MMHg) concentrations were determined in the tissues of demersal shark (Order Squaliformes and the Families: Scyliorhinidae, Hexanchidae) and chimaera species (Families: Chimaeridae and Rhinochimaeridae) from continental shelf and slope waters off southeast Australia, including embryos, juveniles and adults. The distribution of $\mathrm{THg}$ in various tissues (muscle, liver, kidney, and skin), examined in ten species, shows higher levels in the muscle tissue $\left(1.49 \pm 0.47 \mathrm{mg} \mathrm{kg}^{-1}\right.$, ww), which accounted for between $59-82 \%$ of the total body burden of mercury and in the kidney $(0.93 \pm 0.14 \mathrm{mg}$ $\mathrm{kg}^{-1}$, ww) and liver $\left(0.61 \pm 0.25 \mathrm{mg} \mathrm{kg}^{-1}\right.$, ww) with lower levels observed in the skin $(0.12 \pm$ $0.06 \mathrm{mg} \mathrm{kg}^{-1}$, ww). Additional THg determinations were performed in the muscle tissue of five other species allowing geographical and interspecific comparisons. Speciation analysis demonstrated that more than $90 \%$ mercury was bound in muscle tissue as MMHg with higher percentages ( $>95 \%)$ observed in sharks species occupying deeper environments. Species differences were observed. Highest THg levels in the muscle tissue (up to $6.64 \mathrm{mg} \mathrm{kg}^{-1}$ wet weight, ww) were recorded in Proscymnodon plunketi and Centrophorus zeehaani (mean values; $4.47 \pm 1.20$ and $3.52 \pm 0.07 \mathrm{mg} \mathrm{kg}^{-1}$, ww, respectively). Consistent with the ongoing paradigm on mercury bioaccumulation, we systematically observed $\mathrm{THg}$ concentrations increasing with animal size from the embryos to the larger sharks. Embryos of Etmopterus baxteri and Centroselachus crepidater had average levels 0.28 and $0.06 \mathrm{mg} \mathrm{kg}^{-1}$ (ww), while adult specimens reached 3.3 and $2.3 \mathrm{mg} \mathrm{kg}^{-1}$ (ww), respectively. $\mathrm{THg}$ concentrations in Australian sharks were compared with the same genus collected in other world regions. Levels were closer to data reported for East Atlantic than for the epicontinental Mediterranean margins. At a smaller geographical scale, the habitat effect on mercury concentration in sharks seems less clear. Squalid sharks occupying shelf waters showed higher mean mercury levels
\end{abstract}


relative to their size (body weight, bw) than mid-slope species $\left(0.4-6.7 \mathrm{mg} \mathrm{kg}^{-1}\right.$ bw and $0.3-$ $2.2 \mathrm{mg} \mathrm{kg}^{-1}$ bw, respectively). However, local regional differences (East and South Tasmania vs Victoria) in $\mathrm{Hg}$ levels were not detected for the majority of taxa examined. All species, with the exception of Figaro boardmani showed values greater than $0.5 \mathrm{mg} \mathrm{kg}^{-1}$ (ww) and all but four were above many international regulatory thresholds $\left(1.0 \mathrm{mg} \mathrm{kg}^{-1}\right.$, ww).

Keywords: Mercury, methylmercury, deep-sea, body distribution, maternal transfer, Squaliformes, Chimaeriformes, Carcharhiniformes. 


\section{INTRODUCTION}

Mercury $(\mathrm{Hg})$ is a volatile and highly toxic environmental contaminant present in marine systems. In marine organisms, it is most commonly found as monomethylmercury (MMHg), a chemical species formed in hypoxic and suboxic sediments and waters (Cossa et al., 2009). The uptake and bioconcentration of MMHg by marine organisms is a very efficient process. This is largely due to the high permeability through biological membranes of certain neutral complexes (Mason et al., 1995), and its high affinity for proteinaceous material, which retains the molecule within the muscle tissue. Hence, MMHg tends to concentrate in fish tissues as they age (and increase in size) (Boudou and Ribeyre, 1997). In addition, after this rapid uptake (predominantly from food for MMHg in aquatic animals), slow elimination mechanisms cause an increase in methylmercury concentration and proportion with increasing trophic position; a process known as biomagnification through the food chains (Boudou and Ribeyre, 1997). By this process, while MMHg constitutes less than $10 \%$ of the THg in water (Cossa and Coquery, 2005), it constitutes more than $90 \%$ in high-order predators (Bloom 1992). Consequently, mercury concentrations in marine fish appear to be governed mainly by size and trophic position.

Since the well-documented incidences of mercury exposure to human communities in Japan and Iraq, which resulted in severe toxic and teratogenic effects (Harada, 1995), there has been widespread public concern over the consumption of mercury. Because of this, health managers face great challenges in their efforts to better understand how mercury is dispersed in the environment, and to protect the public from exposure to methyl-mercury through the consumption of fish. Currently, the Australian and New Zealand Food Standards Code (FSANZ) prescribes two separate maximum levels for mercury in seafood offered for commercial sale: $1.0 \mathrm{mg} \mathrm{kg}^{-1}$ (wet weight, ww) for fish that are known to contain high levels of mercury (including several large deep-sea fishes, rays and sharks) and $0.5 \mathrm{mg} \mathrm{kg}^{-1}$ (ww) for all smaller species of fish, as well as crustacean and mollusks (FSANZ, 2007). Similar regulations have been taken by other governmental authorities (e.g., EFSA 2008).

In contrast to near-shore organisms, limited data is available on mercury levels in demersal predators, such as sharks. Despite the increasing commercial market for flesh and use of sharks in the pharmaceutical market, few studies have investigated the distribution of mercury in internal tissues of sharks. As many of the sharks tested in this study are commonly consumed in local markets, data will be highly pertinent to health advisors and management boards. Data on some of these shark species are completely lacking or have not been investigated since the 1980's (Walker, 1988). In this framework, the present study provides data on $\mathrm{THg}$ and $\mathrm{MMHg}$ levels in a range of consumed and non-consumed demersal sharks from continental shelf and slope waters off southeastern Australian and investigates variations in their mercury content and compartmentalization (organotropism). Furthermore, the study addresses questions of $\mathrm{Hg}$ over the life cycle, in, embryos, juveniles and size related bioaccumulation within adult sharks, and assesses the effects of habitat. 


\section{METHODS}

\subsection{Sample collection}

A total of 227 individual sharks and chimaeras of 16 demersal species were collected from five sites in continental waters around eastern and southern Tasmania and south of Victoria and South Australia (Table 1). Samples were taken opportunistically as by-catch from local long-line and trawl fishing boats, between November 2004 and June 2006. Specimens were immediately frozen whole before being transported to CSIRO Marine Laboratories, and stored whole at $-20^{\circ} \mathrm{C}$. All sharks were processed within 6 months of being captured, where species were identified, individually weighed and measured. All taxonomic names are based on the most recent literature (Last and Stevens 2009). Stage of maturity was determined by examination of internal and external reproductive organs. Two $100 \mathrm{~g}$ portions of peduncle dorsal muscle tissue were collected in plastic zip-lock bags and stored at $-20{ }^{\circ} \mathrm{C}$. Sections of liver, kidney, and skin were also removed from selected specimens to explore tissue distribution of THg. A constant focus was on obtaining homogenous (representative) tissue samples. To minimize the risk of contamination, samples were placed onto a polyethylene plate and plastic utensils were used and rinsed between each sampling with demineralised water (Milli-Q). All samples taken were freeze-dried and sheltered from light until analysis.

\subsection{Mercury analysis}

Total mercury $(\mathrm{THg})$ determinations were carried out on 2-3 aliquots ranging from 10 $50 \mathrm{mg}$ of dried material and were directly analysed in an flameless Atomic Absorption Spectrophotometry (AAS) using an automatic mercury analyser (AMA-254, Altec) controlled by WinAMA software. In brief, samples were dried at $120^{\circ} \mathrm{C}$ and thermally decomposed at $550^{\circ} \mathrm{C}$ under an oxygen flow to an elemental mercury gold trap (Au-amalgamator) and were quantified by cold-yapour AAS techniques, described in detail by Cossa et al., (2002). The instrument was regularly calibrated using two sets of standard solutions prepared in $0.1 \%(\mathrm{~m} / \mathrm{v})$ $\mathrm{K}_{2} \mathrm{Cr}_{2} \mathrm{O}_{7}$ and $0.6 \%(\mathrm{v} / \mathrm{v}) \mathrm{HNO}_{3}$. This method is also known as the US EPA $\mathrm{N}^{\circ} 7473$. The accuracy and the reproducibility of the method were established using certified reference materials (DORM 2 from the National Research Council of Canada). The accuracy was within the uncertainties of the CRM (Table 1) and reproducibility better than 5\%. The detection limit was $0.007 \mathrm{mg} \mathrm{kg}^{-1}$.

As $\mathrm{MMHg}$ is of greatest concern to organism health due to its toxic and bioaccumulative nature in marine food-webs it was determined for selected muscle tissue samples for 9 of 16 species of shark to confirm approximate percentage of THg. The method for the determination of MMHg in fish tissue is an adaptation for biota of the US EPA method $\mathrm{N}^{\circ} 1630$ described for waters. Briefly, tissue samples are digested using a $\mathrm{NaOH} /$ methanol solution. An ethylating agent is then added to the aqueous sample to form a volatile methyl-ethyl-mercury derivative. The ethylated species are then purged onto Tenax traps as a means of preconcentration and interference removal. The ethylated mercury species are then removed from the traps by heating $\left(250^{\circ} \mathrm{C}\right)$ and separated using isothermal chromatography $\left(70^{\circ} \mathrm{C}\right)$. The mercury species evolving from the chromatography column are destroyed by pyrolysis $\left(800^{\circ} \mathrm{C}\right)$, releasing 
elemental mercury for detection by cold vapor atomic fluorescence spectroscopy (CVAFS) as described in Bloom and Fitzgerald (1988). We used an AFS Tekran, model 2500 for the detection. The detailed protocols are described in Cossa et al. (2002). The method of determination includes the use of the standard addition technique with a MMHg solution in isopropanol. Method precision of MMHg determinations, estimated from 4 replicates of the CRM DORM-2, ranged between $8-15 \%$ (mean 14\%) and its mean recovery was around $90 \%$ (Table 1). The detection limit is $0.004 \mathrm{ng} \cdot \mathrm{mg}^{-1}$.

Calculations of the relative tissue burden were based on a percentage of $\mathrm{THg}$ within a certain tissue relative to the THg in all tissues analysed. Relative contributions of the total body burden relative body burden) of THg (weight normalized) were calculated as the percentage of $\mathrm{THg}$ within the percent proportional tissue relative to the total body weight. Calculations were based on the species-specific weighed average distributions in percentage wet weight (ww) for all tissues (tissue-to-total body ratios) and the tissue-specific ratios derived from published and unpublished data. The proportional liver weight was between 6 to $30 \%$ and kidney 0.9 to $9.0 \%$ of total body weight. Relative weights of the muscle compartment (45-65\% total body weight) were taken as the proportional carcass weights, which exclude the head and fins (Daley et al., 2002). Relative proportions of the skin (denticles) were more difficult to determine, but were estimated at $1.9 \%$ based on the percentage calculation of a $30-\mathrm{cm}^{2}$ section taken from Centroselachus crepidater.

Relative tissue burden $(\%)=\left(\mathrm{THg}\right.$ in tissue compartment $/ \sum \mathrm{THg}$ in all tissues assessed $) \times 100$.

Relative body burden $(\%)=(100 \mathrm{x} \mathrm{THg}$ content in tissue compartment $) /$ Reference tissue proportion.

\subsection{Statistical methods}

To assess interspecies, habitat effects, gender and collection-period variability in $\mathrm{Hg}$ levels, variance (ANOVA) and covariance (ANCOVA) analyses were performed after checking assumptions of normality and homoscedasticity of the data. Where homogeneity was violated, $\mathrm{THg}$ data was log-transformed to stabilize the variance, and the non- parametric Mann-Whitney U test was used. Where assumptions were met, a parametric t-test (assuming unequal variance) was applied to test for significant differences among samples. This included assessing the variations in total mercury, between species, sex, site, maturity and size. Where the number of individuals per species was low $(<10)$, Kruskal-Wallis non-parametric tests were used to make statistical comparisons between species. To explore the relationship between $\mathrm{Hg}$ level and shark length, linear regression analysis was conducted for each species. In each test, $\mathrm{p}<0.05$ was considered significant. 


\section{RESULTS}

\subsection{Levels of THg, MMHg in the muscle and other tissue distribution of THg}

Total mercury levels in the muscle for 227 (16 taxa) demersal sharks were quantified and ranged between 0.21 to $6.64 \mathrm{mg} \mathrm{kg}^{-1}$, ww (1.1-24.5 $\left.\mathrm{mg} \mathrm{kg}^{-1} \mathrm{dw}\right)$, excluding embryos and juveniles, where levels ranged between $0.06-0.41$ and $0.09-0.93 \mathrm{mg} \mathrm{kg}^{-1}$, ww, respectively (Table 2). More than $84 \%$ of all adult individuals examined had mean mercury levels greater than or equal to the $1.0 \mathrm{mg} \mathrm{kg}^{-1}$ (ww) threshold level set by national health regulations of the region (FSANZ 2007). Only one species (non-commercial Figaro boardmani) had mean THg concentrations below $0.5 \mathrm{mg} \mathrm{kg}$ (ww). Highest concentrations were observed in Proscymnodon plunketi (6.64 $\pm 0.04 \mathrm{mg} \mathrm{kg}^{-1}$, ww), Centrophorus zeehaani $\left(4.72 \pm 0.2 \mathrm{mg} \mathrm{kg}^{-1}\right.$, ww), and Squalus mitsukurii ( $3.74 \pm 0.2 \mathrm{mg} \mathrm{kg}^{-1}$, ww), where these values corresponded to the largest individuals assessed for those species.

Methylmercury measurements taken in 13 individuals of 9 shark species showed that it accounts for the majority ( $\geq 91 \%$ ) of THg in shark muscle tissue (Table 3). Lower MMHg concentrations were observed in shelf and upper-slope (90-95\%) than in mid-slope species (>95\%). All mercury determined in P. plunketi, E. baxteri and Dalatias licha was apparently $\mathrm{MMHg}$ as their estimated mean was indistinguishable from $100 \%$. Such results could be accounted for by the relatively high standard errors arising from analytical imprecision in $\mathrm{MMHg}$ analyses (coefficient of variation of $13 \%$ according to results in Table 1) or inherent bio-variability.

Excluding the single juvenile tested, higher levels of $\mathrm{THg}$ were recorded in the muscle tissue (mean $1.49 \pm 0.47 \mathrm{mg} \mathrm{kg}^{-1}, \mathrm{ww}$ ), followed by the kidney ( $0.93 \pm 0.14 \mathrm{mg} \mathrm{kg}^{-1}$, ww), liver $\left(0.62 \pm 0.25 \mathrm{mg} \mathrm{kg}^{-1}\right.$, ww) and skin $\left(0.12 \pm 0.06 \mathrm{mg} \mathrm{kg}^{-1}\right.$, ww $)$, respectively (Table 4). Amongst all species, $68 \%$ (range 59-82\%) of the relative total body burden of mercury was stored in the muscle tissue. The kidney accounted for $2.4 \%(1-5 \%)$, the liver $9.5 \%(1-25 \%)$ and the skin $0.2 \%$ (from below the detection limit to 0.5 ). For most species, liver, kidney and skin tissue presents statistically lower quantities of mercury than muscle $(\mathrm{p}<0.01)$. Unusually large levels of $\mathrm{THg}$ were found in the kidneys of Chimaera lignaria $\left(1.62-1.97 \mathrm{mg} \mathrm{kg}^{-1}\right.$, ww; $4.8 \%$ total body burden) and E. baxteri $\left(0.90-4.16 \mathrm{mg} \mathrm{kg}^{-1}\right.$, ww; $4.8 \%$ total body burden). Comparably high percentage $\mathrm{THg}$ burdens were also found in the livers the two Chimaera species, C. lignaria $\left(0.68-1.49 \mathrm{mg} \mathrm{kg}^{-1}\right.$, ww; $\left.12.8 \%\right)$ and Rhinochimaera pacifica $\left(0.5 \mathrm{mg} \mathrm{kg}^{-}\right.$ 1, ww; 24.8\%). Low levels were observed in the liver and kidney of D. licha (0.7 and $0.9 \%$ relative body burden, respectively) and in the liver of C. zeehaani $(2.1 \%)$. Relatively large variability was observed in the majority of tissues tested.

\subsection{Influence of size and sex on THg of the muscle tissue}

In general, THg in the muscle exceeded $1.0 \mathrm{mg} \mathrm{kg}^{-1}$ (ww) above a shark size of approximately $55 \mathrm{~cm}$. On the basis of the ANCOVA, length differences accounted for $85 \%$, $78 \%$, and $71 \%$ of the total variation in mercury levels observed in C. zeehaani, Squalus mitsukurii and C. crepidater, respectively. Linear relationships were evident between $\mathrm{THg}$ and size for most species, with most regressions being significant with positive slopes, indicating 
that $\mathrm{Hg}$ level increases with increasing length (Figure 1) with lowest values found in embryos and juveniles. R-squared values ranged between 0.43 and 0.98 with more positive correlations observed in C. zeehaani $\left(\mathrm{R}^{2}=0.98, \mathrm{p}<0.001\right)$, S. mitsukurii $\left(\mathrm{R}^{2}=0.88, \mathrm{p}<0.001\right)$, C. crepidater $\left(\mathrm{R}^{2}=0.82, \mathrm{p}<0.001\right)$, and Squalus acanthias $\left(\mathrm{R}^{2}=0.83, \mathrm{p}<0.001\right)$ (Table 5). Analysis of the THg data by size and sex of shark were tested by ANOVA (where class size was $>10$ individuals) revealing significant positive correlations for most, but not all species (Table 6). Stage of maturity correlated with both the length of male and female individuals, and as such, also significantly influenced THg levels. In most species, females were larger and had higher mean total mercury levels than males, except in Deania calcea, $S$. mitsukurii and $R$. pacifica. Sex significantly (ANOVA p $<0.05$ ) influenced THg levels in two species; E. baxteri and $D$. calcea (Table 6). However, when THg levels were normalized with size (using BMI; THg mg $\mathrm{kg}^{-1} / \mathrm{kg} \mathrm{bm}, \mathrm{ww}$ ), higher levels of mercury were in fact observed in males of an equivalent size to females $( \pm 0.5 \mathrm{~cm})$.

\subsection{Geographical, vertical distribution and inter-specific variations}

Mercury concentration varied between species and taxon (Table 1) according to biology and environment (Table 6). No significant relationships between collection site and THg was observed for $C$. crepidater collected in the east and south off Tasmania, nor for sharks of different species collected in the Great Australian Bight and Tasmania. In contrast, some variation in THg concentrations was explained by habitat type, where species were separated by their vertical distribution (shelf and upper-slope $v s$ mid-slope, Table 6). In general, higher mean concentrations of $\mathrm{Hg}$ in sharks appeared in deep-demersal species, although these were not seen to be highly significantly different $(\mathrm{p}=0.058)$. To take away the effects of biological variation (including some effects of size and physiology), species from the Order Squaliformes were pooled together for comparisons of habitat and $\mathrm{THg}$. Squalids occupying the shelf and upper-slope had higher mercury levels relative to their size (BMI) than mid-slope species (0.6 2.5 and $0.3-1.5 \mathrm{THg} / \mathrm{kg} \mathrm{bm}$, respectively). The exception was the mid-slope southern lantern sharks, E. baxteri which showed mean concentration levels of $1.41 \mathrm{THg} / \mathrm{kg} \mathrm{bm}$ and were statistically higher than those of other mid-slope squalids $(\mathrm{p}=0.01)$. In comparison to other taxon groups, the two Scyliorhid species, deepwater catsharks F. boardmani and Apristurus sp. $A$, contained higher BMI levels than the averages of those Squalids occupying similar water bodies. The upper-slope Hexanchid species, Notorynchus cepedianus showed the lowest mercury levels relative to BMI $(0.08-0.1 \mathrm{THg} / \mathrm{kg})$. Regardless of slope habitat, all juveniles displayed similar THg levels (BMI, $0.5-0.9 \mathrm{THg} / \mathrm{kg}$ ). Inter-annual and inter-seasonal variation in $\mathrm{Hg}$ level was investigated and all taxa examined showed no effect for either factor (Table 6). For many species, sample size limitations did not warrant inter-annual and/or regional comparisons. 


\section{DISCUSSION}

The present studies brings new results on the mercury levels in several species of demersal sharks from the Australian waters, in relation to their development stage, size, sex and habitat. In addition, it provides comment on the food safety implications of human consumption of the flesh of these animals.

\subsection{Mercury and shark life-cycle}

Basic information about the mercury pathway and dynamics within the shark may be extracted from the results on $\mathrm{Hg}$ tissue distributions (organotropism) and growth-related $\mathrm{Hg}$ variation (embryos, juveniles, size and sex $\mathrm{Hg}$ dependences).

Organotropism - In some marine organisms, methylmercury tissue concentrations are related to the uptake rate (gill, intestine), others to the demethylation and excretion rate (liver, kidney) (Boening, 2000). In sharks, like most high-order marine predators, dietary mercury is incorporated in a dose-dependant manner (Boudou and Ribeyre, 1997), and is accumulated in internal tissues. Few studies have tested the partitioning of mercury in demersal Chondrichthyes. Horung et al., (1993) reported $\mathrm{THg}$ content in various tissues of five deepwater species (including Centrophorus granulosus, Galeus melastomus and Etmopterus spinax) from the eastern Mediterranean Sea. In all species, they found that higher levels of $\mathrm{Hg}$ were observed in the kidney and 'healthy' livers than in the muscle tissue, with highest (up to 11 times greater in C. granulosus) concentration being observed in unhealthy (very dark) livers. Similarly, in pelagic sharks, Boush and Thieleke (1983) showed that in sexed sharks (Garcharhinus limbatus), significantly higher levels were observed in the liver $\left(0-5.5 \mathrm{mg} \mathrm{kg}^{-1}\right)$ than the muscle tissue ( $\left.0-2 \mathrm{mg} \mathrm{kg}^{-1}\right)$, although the opposite was true for the tiger shark (Galeocerdo cuvieri, $\mathrm{n}=13$ ), which displayed higher THg levels in the muscle tissue $(0.1-0.65$ $\left.\mathrm{mg} \mathrm{kg}^{-1}\right)$ than the liver $\left(0-0.25 \mathrm{mg} \mathrm{kg}^{-1}\right)$, possibly illustrating different physiological capacities to process $\mathrm{Hg}$ between these species.

In this study, the highest mercury concentrations and more than half the total mercury burden were found in the muscle tissue. The kidney showed relatively high $\mathrm{THg}$ levels along with the liver, and minute amounts were found in the denticles (skin). This suggests that mercury is taken up through the diet rather than the environment, and is readily dispersed throughout the body and cumulatively stored in muscle tissue. In contrast, the digestive tissues (kidney and liver) are likely to be associated with metal metabolism, storage and elimination procedures. In species (and individuals) that have relativity higher $\mathrm{Hg}$ concentrations in the kidney (Chimaera lignaria and E. baxteri) and liver (R. pacifica and C. lignaria) than other species, it might suggest either recent exposure followed by concentration in the liver, or strong protein binding, perhaps in a similar manner as has been demonstrated with cadmium by Lucis et al., (1970).

Multiple factors are likely to have contributed to the higher individual variability and different trends in the tissue distribution of mercury observed in demersal sharks by Horung et al., (1993) than in this study. Firstly, although similarities within genera can be drawn, interspecies variability in metabolism and physiology are likely to be large. Secondly, sharks 
studied by Horung et al., (1993) were collected near a deep-water dumpsite, and thus, were atypical (affected by variable and elevated $\mathrm{Hg}$ concentrations from localised pollution).

Influence of size and sex - The linear relationships observed in almost all species demonstrates that larger, presumably older individuals accumulated higher levels of mercury. This pattern has been extensively exhibited in previous studies of sharks (Forrester et al., 1972; Walker, 1976, 1988; Taguchi et al., 1979; Hueter et al., 1995). For C. crepidater analysed in this study, comparable $\mathrm{Hg}$ levels and a similar relationship between size and $\mathrm{Hg}$ levels was observed by Davenport (1995) and Turoczy et al., (2000). The accumulation of mercury with increasing size (fundamentally age) is likely to also reflect other ecological and physical factors, such as differential feeding ecology, and slow and inefficient elimination of mercury from deeper dwelling species (Trudel and Rasmussen, 1997). It is widely recognized that diet is the most important source of $\mathrm{Hg}$ exposure in marine top predators (e.g., Boening 2000). Thus, it can be assumed that the wide range of mercury concentrations observed in this study were a consequence of distinct feeding habits, in addition to other species-specific parameters, such as metabolism and growth rates. Furthermore, data presented here suggest that through bioaccumulation, larger, older adults of these common species potentially contain excessive mercury burdens. Where variability was high in adult individuals, stage of maturity was positively correlated with increasing mercury levels. Ontonogentic variations in diet may also be a considerable factor, particularly where differences are observed between juveniles and adults. In contrast to length, similar THg levels were not often correlated with body weight. This indicates that there is a change in the proportion between size and weight to a certain degree, especially as the shark's shape changes in relation to storage of energy and/or sexual maturity. Although aging, therefore, would have been better than weighing, information on the growth rates of demersal sharks is limited, Aging studies (from spines) of dogfish sharks around Tasmania (Irvine et al., 2006) suggest that our specimens ranged between 15 and 48 years, excluding juveniles. Relationships between aging estimations and size of sharks are thought to be quite variable, possibly explaining some of the observed variability of mercury levels in sharks, particularly where juvenile and sub-adult specimens were also tested.

As a group, females in most species showed higher values than males; however, males that were of a similar length gave higher mean mercury levels. Such phenomena have been observed in S. mitsukurii (Taguchi et al., 1979), and in Squalus megalops (De Pinho et al., 2002). Similar to most elasmobranchs, female demersal sharks have higher growth rates and are larger (sometimes up to 40\%) than males (Daley et al., 2002), displaying sexual dimorphism. This indicates that although males are smaller, they may be of a similar or older age group to larger females. Several species tested in this study have complex population structures, exhibiting segregation by sex, size and mature condition (Daley et al., 2002; Last and Stevens 2009). Differences in mercury levels in males and females may be caused by factors such as energetic requirements, maturation condition, mercury deposition, and transference to eggs and fetuses (Walker, 1976). In sharks that are characterized by viviparous reproduction, due to the transfer of mercury to the fetus, females of some sharks may have 
lower concentrations of mercury than males; however this was not shown to be the case in this study.

Maternal transfer to embryos and juveniles - Because mercury levels increase as individuals grow larger, observed levels in embryos and juveniles can be viewed as the base concentration for the overall population, and indicate the transfer of mercury from maternal sources. Total mercury levels in embryos ranged from $4-10 \%$ of levels observed in their mothers, whose mercury levels were greater than $1.5 \mathrm{mg} \mathrm{kg}^{-1}$. Marginally higher $\mathrm{Hg}$ levels were observed in $E$. baxteri than the sympatric squalid $C$. crepidater, although they are both viviparous and have similar estimated gestation periods (Last and Stevens, 2009). Walker (1976) suggested that transfer of mercury to developing ova and embryos may reduce mercury levels in mature females. In the present study, such relationships were not clearly shown with relatively similar mercury levels recorded in pregnant and non-pregnant females, despite the effects of maternal transfer of mercury to developing ova and embryos. Increased dietary needs, and thus, an increased uptake of MMHg, may be responsible for these similarities.

Adams and McMichael (1990) studied mercury levels in embryos, neonates and juveniles of three Carcharhinid and one Sphyrnid sharks, which have placental viviparous reproduction. All species showed greater mean mercury levels (embryos $0.16-0.78$, juveniles $0.17-1.7$ ) than those reported in this study for both E. baxteri (embryos, $0.2-0.4 \mathrm{mg} \mathrm{kg}^{-1}$, no juvenile data) and C. crepidater (embryo $0.06 \mathrm{mg} \mathrm{kg}^{-1}$, juveniles $0.1-0.5 \mathrm{mg} \mathrm{kg}^{-1}$ ). The reproduction mode, combined with other physiological factors associated with family and habitat differences, conceivably explain why aplacental viviparous shark embryos contained the lowest mean mercury levels in this study. Squalids are viviparous, where nutrients are derived from an associated yolk sac; and thus, high concentrations would possibly be expected due to the direct interchange of nutrients (and presumable mercury) between the mother and embryo via the placenta. Jeffree et al., (2008) showed that that the egg case of dogfish (Scyliorhinus canicula) is highly permeable to chemotoxic metals such as $\mathrm{Hg}$ and that there is much capacity for developing embryos to accumulate very high concentrations of $\mathrm{Hg}$, such as was displayed in this study. In most viviparous sharks, developing oocytes take up large amounts of maternally derived vitellogenin, which consist of about 30\% lipid (Pethybridge et al., in review) and thus lipid metabolism may play a role in transgenerational contaminant transfer (Landrum and Fisher 1998). This pathway would be particularly important for well-known lipophilic contaminants, such as DDT and PCBs but is unlikely to be as important for MMHg which preferentially forms bonds with thiol-containing molecules, such as proteins and amino acids (Bloom 1992). In this regards, it seems vitellogenin (Vtg), a lipophosphoprotein yolk-granule precursor produced in the liver and taken up by developing oocytes (Hamlett and Koob 1999) may have the ideal characteristics in which to transport MMHg to embryos by tightly bounding to sulfhydryl and other sulfur functional groups associated with these proteins.

In juveniles, mercury concentrations were found to be variable amongst species. For juveniles of $S$. acanthias, much lower $\mathrm{Hg}$ levels were found in larger specimens collected in the Celtic Sea (Domi et al., 2005) than were reported in smaller specimens in this study. Greig et al., (1977), found low Hg concentrations in the fetuses of S. acanthias, and concluded that in 
this species mercury does not transfer from the mother to the fetus. Such a conclusion suggests that the higher $\mathrm{Hg}$ levels recorded in the juveniles of $S$. acanthias in this study, compared with Domi et al., (2005), were accumulated after hatching and may be an effect of regional differences in diet.

\subsection{Interspecific, local and regional $\mathrm{Hg}$ variations in sharks muscle tissue}

Information regarding mercury in demersal sharks around the world is scarce. For comparisons with this study, only for the genera Centrophorus, Etmopterus, Squalus, Dalatias, Deania and Chimaera are some published data available (e.g., De Pinho et al., 1989; Hornung et al., 1993 ; Davenport 1995; Turoczy et al., 2000; Storellii et al., 2002; and reviewed by Cossa and Coquery, 2005). Results from the present study are the first published for dogfish, Etmopterus baxteri, Proscymnodon plunketi, chimaeras, Rhinochimaera pacifica, and Chimaera lignaria, and deepwater catshark, Apristurus sp (A and C) and Figaro boardmani. In the following, we contend that mercury concentration in the shark muscle tissue, in addition to size and sex dependence (see subsequent sections), depends on the species and their habitats.

Mercury levels varied greatly amongst species, although noticeably all specimens from the Order Squaliformes had the highest levels of mercury recorded, and mean mercury levels strongly exceeding the $1.0 \mathrm{mg} \mathrm{kg}^{-1}$ (ww) threshold. In comparison, the families Scyliorhidae, Chimaeridae and Rhinochaeridae had relatively lower mean mercury levels $\left(<1.0 \mathrm{THg} \mathrm{mg} \mathrm{kg}^{-1}\right.$, ww). This is not surprising as these families share lower trophic levels (Cortes 1999), and highlights that $\mathrm{Hg}$ uptake is strongly related to diet (Domi et al., 2005). However, the sevengill shark, $N$. cepedianus (Hexanchidae) had the lowest body mass index $(\mathrm{BMI}=0.09$ ) of any species, indicating low accumulative levels despite its known diet of high trophic status (Cortes 1999). Such results emphasize that multiple factors are important in the accumulation of mercury in sharks, including environment, physiology and ecological interactions.

Results of several studies around southeastern Australia (Walker, 1988; Davenport, 1995; Turoczy et al., 2000) show similar mean mercury levels in the muscle tissue to those reported in this study. Comparable elevated levels are also documented in several demersal sharks, globally (De Pinho et al., 2002; Storelli et al., 2002). However, when comparing these results with those of our study, taxon and regional differences in $\mathrm{Hg}$ biomagnification do seem present. For example, Storelli et al. (2002) reported higher concentrations in similar sized specimens of the kitefin shark, D. licha collected from the Ionian Sea (Eastern Mediterranean Sea) than in those of this study. Similarly, in the Portuguese dogfish C. coelolepis, lower concentrations in the muscle were reported in specimens collected off south-eastern Australia (Davenport, 1995 and this study) than those of a similar size range collected from the Mediterranean (Cossa and Coquery, 2005). This is also true for deepwater catshark species, for which higher concentrations have been observed in the Mediterranean (Horung et al., 1993), than in those presented in this study for Figaro boardmani (previously known as Galeus boardmani), while comparable levels have been reported in the Celtic Sea (Domi et al., 2005). Storelli and Marcotrigiano (2002) found that for similar sized specimens of blackmouth dogfish, Galeus melastomus, THg and MMHg concentrations differed substantially among 
those collected from the Adriatic Sea, the Ionian Sea and the Aegean Sea, demonstrating the strong affect that the environment has on mercury uptake. In D. calcea, similar levels were recorded in similar sized species collected from waters of the Mid-Atlantic Ridge (Martins et al., 2006) to those collected off south-east Australia (Davenport, 1995; Turoczy et al., 2000 and this study). In a first attempt, it can be suggested that margin waters from open oceanic environments such as the Australian and Celtic shelves, harbour sharks with lower mercury content than those from an epicontinental environment, such as the various basins of the Mediterranean Sea. However, this generalization is not yet supported by available environmental data. We also have to consider that food chain structure or growth rate differences between Mediterranean sharks and those from other oceanic regions might equally explain these observations. Indeed, the range of MMHg concentrations measured very recently in the water column of the Mediterranean Sea (Cossa et al., 2009), Tasmanian margin (Cossa et al., 2008) and Celtic Sea (Cossa and Chou, unpublished) are similar $\left(<0.01-0.15 \mathrm{ng} \mathrm{L}^{-1}\right)$. Further studies of mercury cycling in the Mediterranean Sea, and the dynamics of the heavy metal in the region's food chains topped by demersal sharks, are required to establish the basis for their greater mercury burden in these waters.

At a smaller geographical scale (East and South Tasmania $v s$ Victoria), the habitat effect on mercury concentration in sharks seems less clear. Differences between shelf/upper-slope species and mid-slope species are noted in our study, although differences between collections sites were not detected for the majority of taxa examined. A lack of variability between taxa and site are likely to indicate similar associations among predatory behavior, longevity, and mercury accumulation processes as has been suggested by Forrester et al. (1972). Furthermore, similarities in diet and base-level mercury concentrations, hydrodynamic patterns, and the movement of the migratory species are additional factors likely to exclude within regional differences in $\mathrm{Hg}$ biomagnification in the sharks reported in this study.

Deep-sea environments are considered to be the sink and final reservoir for contaminants (Tatsukawa and Tanabe, 1984). Deep-sea species are long-lived, and tend to feed at higher trophic levels than their shallow-water counterparts Hence, they are exposed to higher levels of recycled elements for longer periods (Gordon et al., 1995), and the corresponding accumulation of most trace metals is likely to be greater. In this study, higher concentrations appeared in deep-demersal species which may be related to the consumption of prey from different food chains. Sarica et al., (2005) found that marine predators with scavenging behavior have a greater potential to assimilate methylmercury. This seems true in regards to the high levels found in the demersal sharks reported in this study. Alternatively, differences between shelf/upper-slope species and mid-slope species may also be attributed to differences in lipid biochemistry and increasing lipid content in the liver with depth (Pethybridge et al., in review) which may affect the ability of the liver to demethylate mercury.

The absence of any long-term, seasonal or annual differences (summer, winter and 2005, 2006) for the majority of the taxa examined is consistent with the fact that all samples were considered of adult size, and presumably older than 20 years. In a 20 -year accumulation time, a one-year sampling difference is a relatively short time interval in which natural or 
anthropological events could cause environmental changes. Additionally, sharks, being highorder predators with slow metabolisms, accumulate mercury over longer time periods than those occupying the lower trophic levels, leading to greater biomagnification of mercury. For example, Sager (2002) found elevated $\mathrm{Hg}$ levels in predatory fishes 30 years after a local $\mathrm{Hg}$ contaminated water release was ended even though the $\mathrm{Hg}$ level of some fishes at lower trophic levels dropped below the safety level the next year.

\section{Conclusions}

Regardless of species, in all adults, mercury concentrations of the muscle tissue are high enough to cause potential health concerns for sustained and regular human consumption (Harada 1995) and are over the local (FSANZ 2007) and European Union legal limit (EFSA 2008) for mercury in fish of 1.0 and $0.5 \mathrm{mg} \mathrm{kg}^{-1}$ (ww), respectively. $\mathrm{MMHg}$ is the most toxic form of mercury for human consumption, and essentially accounts for the majority (>90\%) of mercury found in fish muscle tissue (e.g., Bloom, 1992), as well as in the sharks studied here. In other studies on sharks (Walker, 1976; Storelli et al., 2002), methylmercury has been recorded to represent between 50-100\% (most exceeding 70\%) of the total mercury content in muscle tissue.

This study has provided information on the contamination status of mercury in demersal Chondrichthyes, which are less studied than teleost fish. The longevity and slow growth rates of demersal sharks, considered in conjunction with their apex predator life-style contribute significantly to the accumulation of high concentrations of mercury that warrant public concern as many species reported here are still being fished and marketed. The variations of mercury concentrations among species are likely to be most affected by the trophic level at which they feed and physiological differences in metal assimilation and metabolic capacity in processing MMHg. Large-scale regional differences in Hg levels seem apparent in Chondrichthyes, which emphasis the important position of the environment and ecology in mercury biomagnification and also stimulate consideration of these high-order predators as environmental monitors. Further research, with increased and targeted sample sizes of certain ubiquitous species, size ranges, and locations would help elucidate the relationship of MMHg to the specific migratory habits and physiology of demersal sharks.

\section{Acknowledgments}

We would like to thank Bernard Averty and Stephan Guedron for their training and assistance with mercury analyses. Thanks are expressed to the captain and crew of the 'Adriatic Pearl' for sample collection. We are grateful to Ross Daley for his helpful comments on demersal shark ecology and help with sample collection. The comments by two anonymous referees are appreciated in improving the text. This project was partly funded by the Goddard SapinJaloustre Trust Fund in association with IFREMER Centre de Nantes, France. 


\section{References}

Adams, D.H., McMichael Jr, R.H., 1990. Mercury levels in four species of sharks from the Atlantic coast of Florida. Fisheries Bulletin 97, 372-379.

Bloom, N.S., Fitzgerald, W.F., 1988. Determination of volatile mercury species at the picogram level by low temperature gas chromatography with cold vapor atomic fluorescence detection. Analytica Chimica Acta 208, 151-161.

Bloom, N.S., 1992. On the chemical form of mercury in edible fish and marine invertebrate tissue. Canadian Journal of Fisheries and Aquatic Science 49, 1010-1017.

Boening, D., 2000. Ecological effects, transport, and fate of mercury: a general review. Chemosphere 40, 1335-1351.

Boudou, A. and Ribeyre, F. 1997. Mercury in the Food Web: Accumulation and Transfer Mechanisms. In: Sigel, H., Sigel A., (Eds.), Mercury and its effects on environment and biology. Vol. 34. Metal Ions in Biological Systems. Dekker, New York, pp. 289-319.

Boush, G., Thieleke, J.R., 1983. Mercury content in sharks. Bullitin of Environmental Contaminants and Toxicology 30, 284-290.

Cortes, E., 1999. Standardized diet compositions and trophic levels of sharks. ICES Journal of Marine Science 56, 707-717.

Cossa, D., Coquery, M., 2005. The Mediterranean mercury anomaly, a geochemical or a biological issue. In Saliot, A., (Eds.). The Handbook of Environmental Chemistry Vol. 5, Springer, Berlin, pp. 177-208.

Cossa, D., Coquery, M., Nahklé, K., Claisse, D., 2002. Dosage du mercure total and du Monométhylmercury dans les organismes et les sédiments marins. Méthodes d'analyse en milieu marin. France: Editions Ifremer, Plouzané. pp. 26.

Cossa, D., Butler, E., Heimbürger, L.E., Averty, B., Bowie, A., Watson, R., Remenyi, T., 2008. Methylmercury distribution in the upper part of the Southern Ocean (SR3, Geotraces). AGU Fall Meeting, San Francisco, 15-19 December 2008. Session C06 (Outcomes from the IPY).

Cossa, D., Averty, B., Pirrone, N., 2009. The origin of methylmercury in open Mediterranean waters Limnology and Oceanography 54 (Suppl. 3), 837-844.

Daley, R., Stevens, J. and Graham, K. 2002. Catch analysis and productivity of the deepwater dogfish resource in southern Australia. FRDC Final Report, 1998/108. Fisheries Research and Development Corporation, Canberra.

Davenport, S., 1995. Mercury in blue sharks and deepwater dogfish from around Tasmania. Australian Fisheries 54 (Suppl. 3), 20-22.

De Pinho, A.P., Guimarães, J.R.D., Martins, A.S., Costa, P.A.S., Olavo, G., Valentin, J., 2002. Total Mercury in Muscle Tissue of Five Shark Species from Brazilian Offshore Waters: Effects of Feeding Habit, Sex, and Length. Environmental Research 89 (Suppl. 3), 250258.

Domi, N., Bouquegneau, JM., Das, K., 2005. Feeding ecology of five commercial shark species of the Celtic Sea through stable isotope and trace metal analysis. Marine Environmental Research 60, 551-569. 
European Food Safety Authority, (EFSA)., 2008. EFSA provides risk assessment on mercury in fish: precautionary advice given to vulnerable groups. Available at: www.efsa.europa.eu Accessed 29.02.2009.

Forrester, C.R., Ketchen, K.S., Wong, C.C., 1972. Mercury content of spiny dogfish, Squalus acanthias, in the Strait of Georgia, British Columbia. Canadian Journal of Fisheries and Aquaculture Science 29 (Suppl. 10), 1487-1490.

Food Standards Australia New Zealand (FSANZ)., 2007. Mercury in fish - Further information. Available at: http://www.foodstandards.gov.au Accessed 29.01.2009.

Gordon, J.D., Merrett, N.R., Haedrich, R.L., 1995. Environmental and biological aspects of slope dwelling fishes of the North Atlantic. In: Hooper A.G., (Eds.), Deep-water Fisheries of the North Atlantic Oceanic Slope, Kluwer, Netherlands, pp. 126.

Greig, R.A., Wenzi-off, C., Shelpunk, L., Adams, A., 1977. Mercury concentrations in three species of fish from North Atlantic waters. Archives of Environmental Contamination and Toxicology 5, 315-323.

Hamlett WC, Koob TJ. 1999. Female reproductive system. In: Hamlet, W., (Eds.), Sharks, skates, and rays the biology of elasmobranch fishes. The Johns Hopkins University Press, London, pp. 398-443.

Harada, M., 1995. Minamata disease: Methylmercury poisoning in Japan caused by environmental pollution. Critical Reviews in Toxicology 25, 1-24.

Hornung, H., Krom, M.D., Cohen, L., Bernhard, M., 1993. Trace metal content in deep-water sharks from the eastern Mediterranean Sea. Marine Biology 115 (Suppl. 2), 331-338

Hueter, R.E., Fong, W.G., Henderson, G., French, M.F., Manire, C.A., 1995. Methylmercury concentration in shark muscle by species, size and distribution of sharks in Florida coastal waters. Water, Air, and Soil Pollution 80, 893-899.

Irvine, S., Stevens, J., Laurenson, L., 2006. Comparing external and internal dorsal-spine bands to interpret the age and growth of the giant lantern shark, Etmopterus baxteri (Squaliformes: Etmopteridae). Environmental Biology of Fishes 77 (Suppl. 3-4), 253-264.

Jeffree, R.A., Oberhansli, F., Teyssie, J.L., 2008. The accumulation of lead and mercury form seawater and their depuration by eggs of the spotted dogfish Scliorhinus canicula (Chondrichthys). Archives of Environmental Contaminant Toxicology 55:451-461.

Last, P.R., Stevens, J.D., 2009. Sharks and rays of Australia. CSIRO Publishing, Australia.

Landrum, P.F., Fisher, S.W., 1998. Influence of lipids on the bioaccumulation and trophic transfer of organic contaminants in aquatic organisms. In: Arts, M., Wainman, B., (Eds), Lipids in Freshwater Ecosystems, Springer, New York, pp. 203-234.

Lucis, O.J., Shaikh, Z.A., Embil, J.A., 1970. Cadmium as a trace element and cadmium binding components in human cells. Experientia 26, 1109.

Martins, I., Costa, V., Porteiro, F.M., Santos, R.S., 2006. Temporal and spatial changes in mercury concentrations in the North Atlantic as indicated by museum specimens of glacier lanternfish Benthosemal glaciale (Pisces: Myctophidae). Environmental Toxicology 21, 528-532.

Mason, R.P., Reinfelder, J.R., Morel, F.M.M., 1995. Bioaccumulation of mercury and methylmercury. Water, Air, and Soil Pollution 80, 915-921.

Pethybridge, H., Nichols, P., Virtue, P., Lipid composition and partitioning in 17 demersal sharks caught off south eastern Australia. In review (May 2009): Marine Biology 
Pethybridge, H., Daley R., Virtue, P., Nichols, P., Reproduction of Deepwater Chondrichthyan: Insights from lipid profiling. In review (June 2009): Marine Biology

Sager, D.R., 2002. Long-term variation in mercury concentrations in estuarine organisms with changes in releases into Lavaca Bay, Texas. Marine Pollution Bulletin 44, 807-815.

Sarica, J., Amyot, M., Hare, L., Blanchfield, P., Bodaly, R.A., Hintelmann, H., Lucotte, M., 2005. Mercury transfer from fish carcasses to scavengers in boreal lakes: the use of stable isotopes of mercury. Environmental Pollution 134, 13-22.

Storelli, M.M., Giacominelli-Stuffler, R., Marcotrigiano, G.O., 2002. Mercury accumulation and speciation in muscle tissue of different species of sharks from the Mediterranean Sea, Italy. Bulletin of Environmental Contaminants and Toxicology 68, 201-210.

Storelli, M.M., Marcotrigiano, G.O., 2002. Mercury speciation and relationship between mercury and selenium in liver of Galeus melastomus from the Mediterranean Sea. Bulletin of Environmental Contaminants and Toxicology 69, 516-522.

Taguchi, M., Yasuda, K., Toda, S., Shimizu, M., 1979. Study of metal contents of elasmobranch fishes: Part 1. Metal concentration in the muscle tissues of a dogfish, Squalus mitsukurii. Marine Environmental Research 2, 239-49.

Tatsukawa, R., Tanabe, S., 1984. Environmental monitoring: geochemical and biochemical behaviour of PCB's in the open ocean environment. In. Barrors, M. C, Konemann, H and Visser, R., (Eds.), Ministry of Housing and Ministry of Agriculture and Fisheries, Netherlands, pp. 99-118.

Trudel, M., Rasmussen, J.B., 1997. Modeling the elimination of mercury by fish. Environment Science Technology 31, 1716-1722.

Turoczy, N.J., Laurenson, L.J.B., Allinson, G., Nishikawa, M., Lambert, D.F., Smith, C., Cottier, J.P.E., Irvine, S.B., Stagnitti. F., 2000. Observations on Metal Concentrations in Three Species of Shark (Deania calcea, Centroscymnus crepidater, and Centroscymnus owstoni) from Southeastern Australian Waters. Journal of Agriculture and Food Chemistry 48, 4357-4364.

Walker, T.I., 1976. Effects of species, sex, length and locality on the mercury content of school shark, Galeorhinus australis, and gummy shark, Mustelus antarcticus, from South-eastern Australian waters. Australian Journal of Marine and Freshwater Research 27, 603-616.

Walker, T., 1988. Mercury concentrations in edible tissues of elasmobranchs, teleosts, crustaceans and molluscs from south-eastern Australian waters. Australian Journal of Marine and Freshwater Research 39, 39-49. 
Table and figures

Table 1. Accuracy of the total mercury (THg) and monomethylmercury (MMHg) determinations using the DORM-2 Dogfish Muscle Certified Reference Material from the National Research Council of Canada. CRM's were analysed every 10-15 samples.

\begin{tabular}{|c|c|c|c|c|}
\hline & $\begin{array}{c}\text { Certified value* } \\
\text { (mg kg-1 }{ }^{-1} \text { dry weight) }\end{array}$ & $\begin{array}{c}\text { Measured value* } \\
\text { (mg kg-1 }{ }^{-1} \text { dry weight) }\end{array}$ & $\begin{array}{l}\text { Relative } \\
\text { error }(\%)\end{array}$ & $\begin{array}{c}\text { Recovery } \\
(\%)\end{array}$ \\
\hline $\mathrm{THg}$ & $4.64 \pm 0.26$ & $4.60 \pm 0.07$ & 0.9 & 99 \\
\hline MMHg & $4.47 \pm 0.32$ & $4.03 \pm 0.55$ & 13.6 & 90 \\
\hline
\end{tabular}

Table 2. Total mercury (THg) concentrations in muscle tissue of deep-sea sharks from southeast Australia. Results are presented as range (min - max) $\mathrm{THg} \mathrm{mg} \mathrm{kg}^{-1}$ (ww) (mean $\pm \mathrm{SD}$ ). $\mathrm{THg}$ Body Mass Index (BMI) is calculated as THg mg. $\mathrm{kg}^{-1}$ per $\mathrm{kg}$ of body mass (ww). F: female; M: male.

\begin{tabular}{|c|c|c|c|c|c|}
\hline $\begin{array}{l}\text { Order } \\
\text { Species }\end{array}$ & GROUP (n) & $\begin{array}{l}\text { Length } \\
\text { (cm) Range }\end{array}$ & $\begin{array}{l}\text { Weight } \\
\text { (kg) Range }\end{array}$ & THg & THg BMI \\
\hline \multicolumn{6}{|c|}{ Mid-slope $(600-1500 \mathrm{~m})$} \\
\hline Squaliformes & & & & & \\
\hline \multirow[t]{2}{*}{ Etmopterus baxteri } & Adults (40) & $52-89$ & $0.8-2.5$ & $1.2-3.3(2.2 \pm 0.6)$ & $0.8-2.2$ \\
\hline & Embryo's (3) & $4-8$ & $0.1-0.2$ & $0.2-0.4$ & $2.0-2.6$ \\
\hline \multirow[t]{3}{*}{ Centroselachus crepidater } & Adults (36) & $63-94$ & $1.1-3.8$ & $0.8-2.3(1.5 \pm 0.4)$ & $0.3-1.5$ \\
\hline & Juveniles $\mathrm{F}(6)$ & $34-50$ & $0.2-0.6$ & $0.1-0.5(0.3 \pm 0.1)$ & $0.7-1.3$ \\
\hline & Embryo's (1) & 4.8 & 0.09 & 0.06 & 0.6 \\
\hline Centroscymnus owstoni & Adults (4) & $75-80$ & $2.0-2.3$ & $2.3-2.5$ & 1.2 \\
\hline Centroscymnus coelopsis & Adults (4) & $76-78$ & $2.1-2.4$ & $2.3-2.5$ & $0.9-1.1$ \\
\hline Deania calcea & Adults (16) & $78-95$ & $1.8-3.9$ & $1.2-2.3(1.7 \pm 0.3)$ & $0.4-1.0$ \\
\hline Dalatias licha & Adults (5) & $98-116$ & $4.5-9.3$ & $1.2-2.2(1.6 \pm 0.4)$ & $0.2-0.3$ \\
\hline Proscymnodon plunk & Adults (7) & $112-145$ & $9.8-24.8$ & $3.1-6.6(4.5 \pm 1.2)$ & $0.3-0.5$ \\
\hline \multicolumn{6}{|l|}{ Chimaeriformes } \\
\hline Chimaera lignaria & Adults (13) & $60-107$ & $1.2-5.5$ & $0.4-1.4(0.9 \pm 0.3)$ & $0.1-0.5$ \\
\hline Rhinochimaera pacifica & Adults (8) & $98-120$ & $1.8-4.2$ & $0.5-0.8(0.5 \pm 0.1)$ & $0.1-0.4$ \\
\hline \multirow{2}{*}{$\begin{array}{l}\text { Carcharhiniformes } \\
\text { Apristurus sp. A/C }\end{array}$} & & & & & \\
\hline & $\begin{array}{l}\text { AduIts (2) } \\
\text { Juyeniles (3) }\end{array}$ & $\begin{array}{l}69-72 \\
54-58\end{array}$ & $\begin{array}{l}1.0-1.1 \\
06-07\end{array}$ & $\begin{array}{l}1.5-1.7 \\
02-0.9\end{array}$ & $\begin{array}{l}1.5-1.6 \\
04-12\end{array}$ \\
\hline \multicolumn{6}{|c|}{ Shelf and Upper-slope (0-600 m) } \\
\hline \multicolumn{6}{|l|}{ Squaliformes } \\
\hline \multirow{2}{*}{ Centrophorus zeehaani } & Adults M (10) & $82-90$ & $3.1-4.2$ & $2.6-4.7(3.5 \pm 0.7)$ & $0.7-1.3$ \\
\hline & Juveniles M (3) & $55-62$ & $0.7-0.8$ & $0.4-0.8(0.6 \pm 0.2)$ & $0.6-1.0$ \\
\hline \multirow[t]{2}{*}{ Squalus acanthias } & Adults (10) & $77-85$ & $2.1-2.7$ & $0.8-1.8(1.4 \pm 0.4)$ & $0.4-0.7$ \\
\hline & Juveniles (8) & $60-75$ & $1.0-2.0$ & $0.4-0.7(0.5 \pm 0.1)$ & $0.3-0.4$ \\
\hline Squalus megalops & Adults M (10) & $42-57$ & $0.2-1.1$ & $0.6-2.1(1.4 \pm 0.5)$ & $1.3-6.7$ \\
\hline \multirow[t]{2}{*}{ Squalus mitsukurii } & Adults (13) & $69-80$ & $1.6-2.5$ & $1.8-3.7(2.6 \pm 0.7)$ & $1.0-2.0$ \\
\hline & Juveniles M (8) & $40-48$ & $0.3-0.5$ & $0.8-1.0(0.9 \pm 0.1)$ & $1.8-3.5$ \\
\hline \multicolumn{6}{|l|}{ Carcharhiniformes } \\
\hline $\begin{array}{l}\text { Figaro boardmani } \\
\text { Hexanchiformes }\end{array}$ & Adults F (11) & $38-51$ & $0.1-0.5$ & $0.2-1.2(0.4 \pm 0.4)$ & $0.9-2.6$ \\
\hline Notorynchus cepedianus & Adults F (2) & $153-158$ & $14.6-15.7$ & $1.2-1.5$ & $0.8-0.9$ \\
\hline
\end{tabular}


Table 3. Percentage (\%) of MMHg (mg kg $\left.{ }^{-1} \mathrm{dw}\right)$ that accounts for $\mathrm{THg}\left(\mathrm{mg} \mathrm{kg}^{-1} \mathrm{dw}\right)$. Values are taken as the mean from 1-4 replicates were performed on each individual. $n$ : number of determination.

\begin{tabular}{lcccc}
\hline $\begin{array}{l}\text { Habitat } \\
\quad \text { Species (n) }\end{array}$ & Sex & THg & MMHg & MMHg/THg (\%) \\
\hline Mid-slope & & & & \\
$\quad$ C. crepidater (2) & $\mathrm{F}$ & $7.5-8.0$ & $7.1-7.8$ & $94.6-97.5$ \\
C. owstoni & $\mathrm{F}$ & 10.0 & 9.6 & 95.8 \\
D. licha & $\mathrm{M}$ & 8.4 & 8.5 & 101.3 \\
E. baxteri & $\mathrm{F}$ & 10.8 & 11.0 & 101.1 \\
$\quad$ P. plunketi (2) & $\mathrm{M}$ & $17.5-20.6$ & $17.1-21.3$ & $97.5-103.4$ \\
Shelf and Upper-slope & & & & 9.3 \\
$\quad$ S. acanthias & $\mathrm{F}$ & 6.0 & 5.6 & 91.3 \\
S. megalops & $\mathrm{F}$ & 6.9 & 6.3 & 94.3 \\
S. mitsukurii & $\mathrm{F}$ & 10.5 & 9.9 & \\
\hline
\end{tabular}

Table 4. Range (min - max) of total mercury concentrations ( $\mathrm{mg} \mathrm{kg}^{-1}$, ww) in the tissues of ten species of shark from south eastern Australia. Wet weight (ww) conversion factor is the \% of total water content and was used to convert dry mass concentrations to wet mass. Relative tissue burden is calculated as the proportion of mercury $\left(\mathrm{mg} \mathrm{kg}^{-1}\right.$, ww) within a certain tissue relative to all other tissues tested. Relative body burden is calculated as percent (\%) THg in a tissue relative to the tissues contribution to the whole body weight. n: number of determination.

\begin{tabular}{|c|c|c|c|c|c|}
\hline & & Muscle & Liver & Kidney & Skin \\
\hline ww Conversion factor: & & $22-26$ & $7-9$ & $15-16$ & 16-19 \\
\hline Species $(\mathrm{n})$ & Length $(\mathrm{cm})$ & \multicolumn{4}{|c|}{ Total mercury (THg) } \\
\hline C. crepidater (3) & $80-88$ & $1.05-1.60$ & $0.24-0.46$ & $0.67-0.81$ & $0.11-0.28$ \\
\hline C. crepidater pup (1) & 34.6 & 0.12 & 0.02 & 0.05 & 0.00 \\
\hline C. lignaria (2) & $106-111$ & $0.86-1.15$ & $0.68-1.49$ & $1.62-1.97$ & $0.11-0.26$ \\
\hline C. zeehaani (1) & 82.5 & 2.47 & 0.18 & 1.05 & 0.02 \\
\hline D. licha (1) & 98.8 & 1.06 & 0.49 & 0.27 & 0.13 \\
\hline E. baxteri (4) & $56-98$ & $1.55-2.86$ & $0.47-1.3$ & $0.90-4.16$ & $0.10-0.19$ \\
\hline P. plunketi (3) & $112-126$ & $2.69-4.50$ & $0.84-1.34$ & $1.67-1.84$ & $0.17-0.24$ \\
\hline R. pacifica (1) & 112 & 0.4 & 0.5 & 0.17 & 0.08 \\
\hline S. acanthias (2) & $75-82$ & $0.64-1.45$ & $0.61-0.83$ & - & $0.12-0.18$ \\
\hline S. megalops (2) & $44-48$ & $0.75-0.79$ & $0.38-0.70$ & 0.28 & $0.03-0.1$ \\
\hline S. mitsukurii (2) & $75-79$ & $2.83-3.23$ & - & $1.35-1.63$ & 0.14 \\
\hline Relative tissue burden & Average & 50.3 & 22.4 & 27.4 & 4.4 \\
\hline$(\%)$ & Range & $26.2-66.4$ & $4.9-42.3$ & $13.7-47.7$ & $0.5-6.9$ \\
\hline Proportion tissue of $w$ & e weight $(\%) *$ & $45-65$ & $6-30$ & $1-4$ & 1.9 \\
\hline Relative total body & Average & 68.1 & 9.5 & 2.4 & 0.2 \\
\hline burden $(\%)$ & Range & $59.1-81.8$ & $1.0-24.8$ & $0.9-4.8$ & $0.0-0.5$ \\
\hline
\end{tabular}

* Proportion tissue burden (\%) is the tissue-to-total body ratio for each specified tissue, and is taken from published (muscle: Daley et al., 2002) and unpublished data. 
Table 5. Regression analysis of $\mathrm{Log}(\mathrm{THg})$ level as a function of size for demersal sharks species. Significant linear functions $(\mathrm{Y}=\mathrm{a}+\mathrm{bx})$ were fitted. $\mathrm{Y}=\mathrm{Log}(\mathrm{THg})$ level $\left(\mathrm{mg} \mathrm{kg}^{-1} \mathrm{ww}\right), \mathrm{x}$ is total length $(\mathrm{cm})$. The estimated intercept (a), slope (b), $\mathrm{R}^{2}$ value and $\mathrm{P}$ value are listed by species. Equations based on all data, regardless of location and time of collection, except where outliers were present in the data set. n: number of determination.

\begin{tabular}{lcccc}
\hline Species $(\mathrm{n})$ & $\mathrm{a}$ & $\mathrm{b}$ & $\mathrm{R}^{2}$ & P-value \\
\hline C. crepidater (42) & 1.10 & 0.015 & 0.82 & $>0.001$ \\
C. lignaria $(14)$ & 0.67 & 0.007 & 0.68 & 0.012 \\
C. zeehaani $(13)$ & 1.92 & 0.029 & 0.98 & $>0.001$ \\
E. baxteri $(40)$ & 0.27 & 0.009 & 0.43 & 0.010 \\
D. calcea $(19)$ & -0.27 & 0.005 & 0.24 & 0.075 \\
S. mitsukurii $(21)$ & 0.64 & 0.061 & 0.88 & $>0.001$ \\
S. acanthias $(18)$ & 2.29 & 0.054 & 0.83 & $>0.001$ \\
S. megalops $(15)$ & -0.61 & 0.009 & 0.06 & 0.171 \\
F. boardmani $(11)$ & 2.36 & 0.065 & 0.78 & $>0.001$ \\
\hline
\end{tabular}

Table 6. Probability values for species-specific ANOVA results examining sex, year, season and location effect on THg levels. $* \mathrm{P}<0.05$, N/A: insufficient data for statistical treatment. Mid-slope species consist of E. baxteri, C. crepidater and D. calcea; Upper-slope species consists of $S$. acanthias and S. mitsukurii. All species includes all adult species collected in this study.

\begin{tabular}{|c|c|c|c|c|c|c|}
\hline Species / group & $\begin{array}{c}\text { Sex } \\
\text { M vs. F }\end{array}$ & $\begin{array}{c}\text { Year } \\
2005 \text { vs. } 06\end{array}$ & $\begin{array}{l}\text { Season } \\
\mathrm{S} v \text { vs. W }\end{array}$ & $\begin{array}{l}\text { Location } \\
\text { Tas } v s . \text { Vic }\end{array}$ & $\begin{array}{c}\text { Maturity } \\
1,2 \text { vs. }>3\end{array}$ & $\begin{array}{c}\text { BMI }(\mathrm{THg} / \mathrm{kg}) \\
\text { vs. Sex }\end{array}$ \\
\hline C. crepidater & 0.111 & N/A & 0.274 & 0.253 & $0.009 *$ & $0.015 *$ \\
\hline D. calcea & & N/A & N/A & N/A & $0.023 *$ & 0.053 \\
\hline E. baxteri & $.031^{*}$ & 0.326 & 0.356 & N/A & $0.012 *$ & $0.01 *$ \\
\hline S. mitsukurii & 0.093 & N/A & N/A & N/A & $0.032 *$ & $0.022 *$ \\
\hline Mid- vs Upper-slope & 0.127 & N/A & 0.124 & 0.058 & 0.072 & $0.032 *$ \\
\hline All species & 0.346 & 0.427 & 0.267 & N/A & $0.041 *$ & $0.029 *$ \\
\hline
\end{tabular}




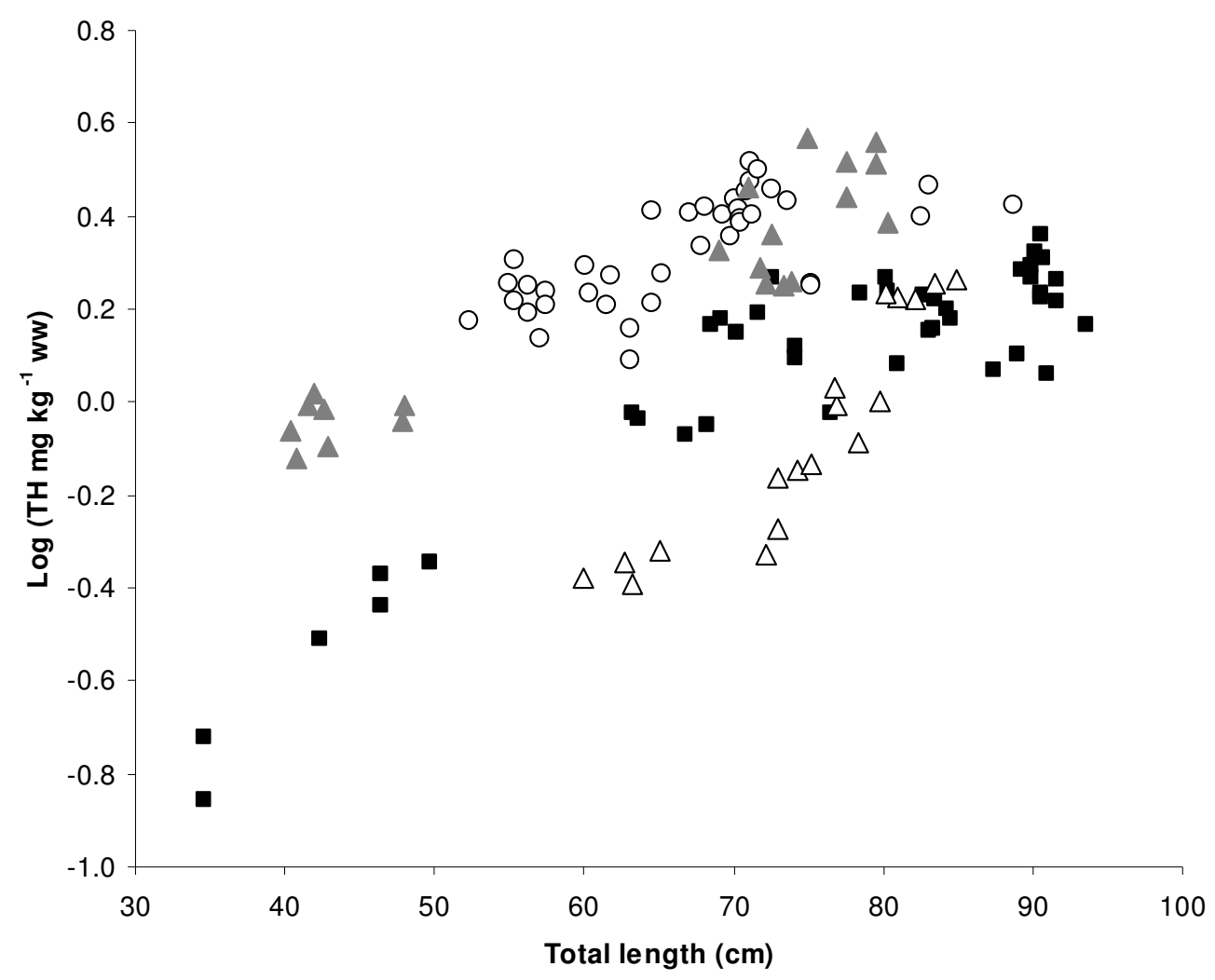

Figure 1. $\log _{10}(\mathrm{THg})$ concentration of shark muscle $v$ s total length $(\mathrm{cm})$ for four shark species: • Centroselachus crepidater, • Etmopterus baxteri, Squalus acanthias, • Squalus mitsukurii 